\title{
Enhanced antiplasmin activity in acute renal failure
}

\author{
A KANFER, A VANDEWALlE, M BEAUFILS, F DELARUE, J D SRAER
}

British Medical fournal, 1975, 4, 195-197

\section{Summary}

Plasmatic slow plasmin-inhibitor activity was assessed in 20 patients with acute renal failure and 12 controls with the fibrin plate method. The area of fibrinolysis was $250.5 \pm 5 \mathrm{~mm}^{2}$ in the patients and $289 \pm 6 \mathrm{~mm}^{2}$ in the controls $(P<0.001)$ and was negatively correlated with antiplasmin activity. Thirteen patients had areas of lysis equal to or inferior to the minimal lysis observed in the controls. No correlation was found between antiplasmin activity and serum fibrin-fibrinogen related antigen titres, the presence or absence of disseminated intravascular coagulation, or the causative disease.

\section{Introduction}

Several features of acute renal failure (ARF) strongly suggest that local (intrarenal) or disseminated intravascular coagulation (DIC) has a role in its pathogenesis. ${ }^{1}$ The most important are that (a) similar conditions can lead to DIC and to ARF, these two syndromes often being associated ${ }^{2}{ }^{3} ;(b)$ fibrinogen catabolism is raised in ARF, ${ }^{4}$ and abnormally high concentrations of fibrin-fibrinogen related antigen (FRA; fibrin degradation products) are often found in patients' $\operatorname{sera}^{5-8}$; and (c) fibrin deposits or platelet aggregates have been shown by light or electron microscopy in acutely ischaemic kidneys, ${ }^{9-11}$ suggesting insufficient secondary fibrinolysis. Impairment of fibrinolysis enhances tissue damage due to intravascular coagulation. ${ }^{12}$ To our knowledge only one work has been published on plasmatic slow-acting plasmin inhibitor (PSPI) in ARF. 7 Our study was designed to investigate further the role of altered antiplasmin activity in ARF and to attempt to correlate clinical data with coagulation-fibrinolysis findings.

\section{Patients and methods}

Twenty adult patients referred to the renal intensive care unit were studied. The criteria for defining ARF were a rapid rise of blood urea and creatinine accompanied by severe oliguria or anuria. In 19 cases an obvious causative disease was present. Percutaneous renal biopsy was performed in seven cases (see table). Blood samples were taken during the first few hours after admission, before the start of haemodialysis or peritoneal dialysis. Three patients in whom renal function had improved three to four weeks after admission were also studied.

\section{PSPI ACTIVITY}

PSPI activity was determined using the fibrin plate lysis technique according to the modifications of Ekelund et al. ${ }^{13} 14$ Blood from the anterior cubital vein was drawn into EDTA, and the plasma was separated and frozen at $-20^{\circ} \mathrm{C}$ and tested within one month. Fibrin

\footnotetext{
Service de Néphrologie and Unité de Recherches de Néphrologie Normale et Pathologique U64 de l'INSERM, Hopital Tenon, 75020 Paris, France

A KANFER, MD, assistant chief of clinic

A VANDEWALLE, $M D$, intern

$M$ BEAUFILS, MD, intern

F DELARUE, technician

J D SRAER, MD, assistant chief of clinic
}

plates were prepared with plasminogen-free fibrinogen (Centre National de Transfusion Sanguine, Paris) at $1 \mathrm{~g} / 1$ concentration; $10 \mathrm{ml}$ of fibrinogen containing $0.1 \mathrm{ml}$ thrombin (Hoffmann-Laroche) at a concentration of 20 National Institutes of Health units $/ \mathrm{ml}$ in $0.025-M$ $\mathrm{CaCl}_{2}$ was poured on to a glass slide measuring $10 \times 8.5 \mathrm{~mm}$. For 20 minutes $50 \mu \mathrm{l}$ of $1 / 30$ diluted plasma was incubated at room temperature with $50 \mu \mathrm{l}$ of human plasmin (Kabi, Stockholm) at a final concentration of 1 Sgouris unit/ml. Then $25 \mu$ l of the mixture was applied to the fibrin plate and incubated for 18 hours at $37^{\circ} \mathrm{C}$. The area of lysis was calculated as the product of two perpendicular diameters and was a measurement of the remaining plasmin activity. It was negatively correlated with antiplasmin activity. All measurements were made in triplicate for every patient.

Control plasma samples were obtained from 12 healthy members of the hospital staff and a pool of plasma was obtained from eight control subjects. The patients' plasma was tested simultaneously with one or more of the 12 control plasma samples and with the pool of control plasma. The area of lysis with 1 unit/l of plasmin in Michaelis buffer was also read on each slide. $P$ values were obtained by means of Student's $t$ test.

\section{OTHER COAGULATION-FIBRINOLYSIS ASSAYS}

The following factors were determined: FRA (Thrombowellcotest), ${ }^{15}$ platelet count (Thrombocoulter), Quick prothrombin time, fibrinogen assay (gravimetric method), ${ }^{16}$ and euglobulin lysis time (ELT).

When the platelet count was less than $120 \times 10^{9} / 1\left(120000 / \mathrm{mm}^{3}\right)$, the Quick prothrombin time less than $50 \%$, and the fibrinogen concentration less than $2 \mathrm{~g} / \mathrm{l}$ or when two our of three tests were abnormal with the serum FRA titre above $32 \mathrm{mg} / 1^{17}$ we considered DIC to be present.

\section{Results}

\section{PSPI ACTIVITY}

The mean value of the area of lysis ( $t$ SE of mean) for the 20 patients was $250.5 \pm 5 \mathrm{~mm}^{2}$ compared with $289 \pm 6 \mathrm{~mm}^{2}$ for the controls. This difference was highly significant $(P<0.001)$ and showed enhancement of PSPI activity in patients with ARF. There was no significant difference between the mean value of the control plasma and that obtained by the plasma pool $\left(292.5 \pm 5.2 \mathrm{~mm}^{2}\right)$. The mean fibrin lysis by plasmin plus Michaelis buffer was $389 \pm 9 \mathrm{~mm}^{2}$ (23 tests).

The results are summarised in the table and the diagram. Some overlapping between the values obtained with the patients' plasma and control plasma were obvious (see fig). Nevertheless, 13 patients had areas of lysis equal to or less than the smallest area of lysis observed in the controls.

PSPI activity was measured in three patients after improvement of renal function with a return to near normal serum creatinine levels $(<177 \mu \mathrm{mol} / 1(<2 \mathrm{mg} / 100 \mathrm{ml}))$. Areas of lysis during the period of oliguria in the three patients were $243 \pm 10 \mathrm{~mm}^{2}, 199 \pm 9 \mathrm{~mm}^{2}$, and $228 \pm 4 \mathrm{~mm}^{2}$. After diuresis the values were $228 \pm 14,191 \pm 2$, and $201 \pm 18 \mathrm{~mm}^{2}$ respectively, which suggested that PSPI activity increased in all three patients with improvement of renal function.

OTHER COAGULATION FIBRINOLYSIS FINDINGS AND CLINICAL CORRELATIONS

DIC occurred in four patients (cases $5,9,16$, and 17) and could not be definitely excluded in three others (cases 8,10 , and 18), in whom two out of four tests were abnormal. In no patients was diminished ELT shown. No statistical correlation was undertaken, but a wide range of areas of lysis was observed in the four patients with DIC (237-303 $\left.\mathrm{mm}^{2}\right)$, and no trend was seen in the relation between the 
Results in 20 patients with ARF. Area of fibrinolysis is expressed as mean ( $\pm S E$ of mean) of triplicate assay

\begin{tabular}{|c|c|c|c|c|c|c|}
\hline $\begin{array}{l}\text { Case } \\
\text { No }\end{array}$ & Diagnosis & $\begin{array}{l}\text { Pathologica! } \\
\text { findings }\end{array}$ & $\underset{\substack{\text { Area of } \\
\text { fibrinolysis } \\
\left(\mathrm{mm}^{2}\right)}}{ }$ & $\begin{array}{c}\text { Serum FRA } \\
\text { range } \\
(\mathrm{mg} / \mathrm{l})\end{array}$ & DIC & $\underset{(\mathrm{h})}{\mathrm{ELT}}$ \\
\hline $\begin{array}{r}1 \\
2 \\
3 \\
4 \\
5 \\
6 \\
7 \\
8 \\
9 \\
10 \\
11 \\
12 \\
13 \\
14 \\
15 \\
16 \\
17 \\
18 \\
19 \\
20\end{array}$ & $\begin{array}{l}\text { Hemolysis } \\
\text { Hemolysis } \\
\text { Shock } \\
\text { Sepsis } \\
\text { Shock } \\
\text { Hemolysis (post partum) } \\
\text { Shock } \\
\text { Sepsis } \\
\text { Shock } \\
\text { Sepsis } \\
\text { Sepsis } \\
\text { Sepsis } \\
\text { Post partum } \\
\text { Sepsis (pregnancy) } \\
\text { Sepsis Hemolysis (post abortum) } \\
\text { Shock Hemolysis (post partum) } \\
\text { Hemolysis } \\
\text { Sepsis } \\
\text { Hemolysis } \\
\text { Sepsis (?) }\end{array}$ & $\begin{array}{l}\text { ATN } \\
\text { ATN } \\
\text { ATN } \\
\text { ATN } \\
\text { BCN } \\
\text { AIN }\end{array}$ & $\begin{array}{l}327 \pm 23 \\
228 \pm 14 \\
288 \pm 17 \\
200 \pm 6 \\
279 \pm 9 \\
243 \pm 10 \\
187 \pm 6 \\
230 \pm 14 \\
303 \pm 9 \\
246 \pm 10 \\
250 \pm 18 \\
233 \pm 1 \\
255 \pm 29 \\
246 \pm 0 \cdot 3 \\
221 \pm 4 \\
237 \pm 8 \\
294 \pm 13 \\
313 \pm 9 \\
199 \pm 9 \\
228 \pm 4\end{array}$ & 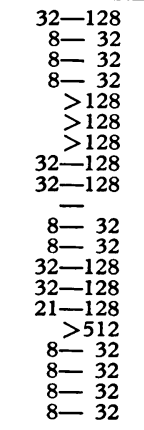 & $\begin{array}{l}0 \\
0 \\
0 \\
0 \\
+ \\
0 \\
0 \\
0 \\
+ \\
0 \\
0 \\
0 \\
0 \\
0 \\
0 \\
+ \\
+ \\
0 \\
0 \\
0\end{array}$ & $\begin{array}{l}>3 \\
>3 \\
>3 \\
>3 \\
>3 \\
\geq 1 \\
>3 \\
= \\
>3 \\
>3 \\
>3 \\
>3 \\
>3 \\
>1 \\
>3 \\
>3 \\
>3\end{array}$ \\
\hline
\end{tabular}

ATN = Acute tubular nephritis. $\quad \mathrm{BCN}=$ Bilateral cortical necrosis. $\quad$ AIN $=$ Acute interstitial nephritis.

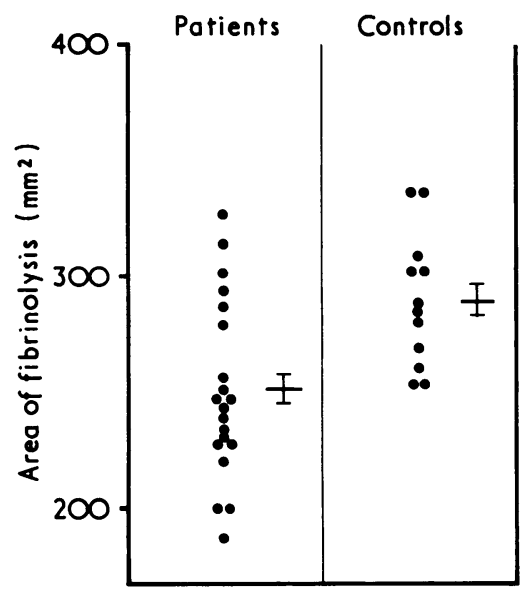

Area of fibrinolysis in 20 patients with ARF and 12 controls. Each point represents mean of triplicate assay. Horizontal line and bar indicate mean value ( \pm SE of mean).

concentration of serum FRA and antiplasmin activity-for example, two patients (cases 7 and 19) had high antiplasmin values with different levels of serum FRA whereas in cases 5 and 7 high and low antiplasmin values occurred with the same value of serum FRA. Furthermore, there was obviously no relation between the type of causative disease and the antiplasmin activity.

\section{Discussion}

Our findings provide evidence that PSPI activity, as measured by the inhibition of fibrin plate lysis, is enhanced in most patients with ARF. Larsson observed increased urokinase inhibitors in seven patients with ARF but reported no change in PSPI values. ${ }^{7}$ We cannot explain this discrepancy since similar methods were used, but our investigation covered more patients. ELT has been found to be normal in patients with $\mathrm{ARF},{ }^{3}$ and we confirmed this result.

ARF is a "vasomotor nephropathy,"18 during which cortical arteriolar vasconstriction is constantly observed and is thought to be responsible, at least in part, for the arrest of glomerular filtration and ischaemic lesions of the kidney ${ }^{1920}$; in many cases vasconstriction could be accompanied or complicated by local intravascular coagulation, possibly leading to cortical necrosis, as emphasised several years ago by Vassalli and Richet, ${ }^{21}$ and more recently by others. ${ }^{2}{ }^{22}$ On this hypothesis any inhibition of fibrinolysis would be detrimental. Human bilateral cortical necrosis is especially associated with pregnancy, during which fibrinolysis is impaired, partly because of the decrease of plasminogen activators. ${ }^{23}$ Furthermore, one case of acute tubular nephritis with glomerular thrombosis after anti-fibrinolytic treatment by epsilon-aminocaproic acid in man has been published. ${ }^{24}$ In animals, likewise, pregnancy and epsilonaminocaproic acid administration facilitate Shwartzman phenomenon by allowing bilateral cortical necrosis after thrombin infusion or one single injection of endotoxin. ${ }^{12}$

PSPI, when increased in vitro, accelerates inactivation of plasmin in vitro. ${ }^{25}$ In human diseases other than ARF increased levels of antiplasmin are probably pathophysiologically important. ${ }^{26} 27$ Enhanced antiplasmin activity has been found in association with thrombosis ${ }^{27} 28$ and in women taking oral contraceptives, ${ }^{29}$ during which an increased risk of thrombosis is well known. Our results, though showing enhanced PSPI activity, do not afford proof of the pathogenetic significance of this abnormality in ARF. Several patients had normal PSPI values, and in the three patients studied after improvement of renal function there was no return of PSPI activity to normal during the study. We cannot deduce whether the enhanced PSPI values observed were a consequence of the initial disease or ARF, or both, or whether they existed before them. Moreover, we would have expected a correlation between serum FRA titres and PSPI values-for example, possibly a high serum FRA titre with low PSPI values-and this was not found. Serum FRA may not be a good index of efficient local fibrinolytic activity: thus in transplanted patients during graft rejection serum FRA rises. ${ }^{8}$ Cortical fibrinolytic activity, however, has not been found in renal biopsy specimens studied by a fibrin slide technique in such patients. ${ }^{30}$

We thank Dr L Morel-Maroger for performing and reading renal biopsies and Dr $M$ Smith for helpful criticism. This work was supported by a grant from DGRST and by INSERM (ATP 17), and AK received a grant from the Corps Médical Hospitalier.

\section{References}

1 Wardle, E N, Clinical Nephrology, 1974, 2, 85.

2 Haanen, C, Holdrinet, A, and Wijdeveld, P, Scandinavian fournal of Haematology, 1971, suppl 13, p 337.

${ }^{3}$ Kleinknecht, D, Kanfer, A, and Josso, F, Revue Européene d'Etudes Cliniques et Biologiques, 1972, 17, 695.

4 Wardle, E N, Quarterly fournal of Medicine, 1973, 42, 205.

5 Haanen, C, et al, Scandanavian fournal of Haematology, 1971, suppl 13, p 345.

6 Hedner, U, and Nilsson, I M, Acta Medica Scandinavica, 1971, 189, 471.

7 Larsson, S O, Scandinavian fournal of Haematology, 1971, suppl 15, p 4.

${ }^{8}$ Hedner, U, and Nilsson, I M, Actualités Néphrologiques de l'Hôpital Necker, 1973, 17, 257. 
${ }^{9}$ Koffler, D, and Paronetto, F, American fournal of Pathology, 1966, 49, 383.

10 Ben-Ishay, Z, Israel fournal of Medical Sciences, 1967, 3, 191.

11 Clarkson, A R, et al, Quarterly fournal of Medicine, 1970, 39, 585.

${ }^{12}$ McKay, D G, in Thrombosis et Diathesis Haemorrhagica, 1969.

13 Astrup, T, and Mullertz, S, Archives of Biochemistry and Biophysics, 1952, 40, 346.

14 Ekelund, H, Hedner, U, and Astedt, B, Acta Paediatrica Scandinavica, $1970,59,369$.

15 Garvey, M B, and Black, J M, Fournal of Clinical Pathology, 1972, 25, 680.

${ }^{16}$ Gram, H C, Fournal of Biological Chemistry, 1921, 49, 279.

${ }^{17}$ Colman, R W, Robboy, S J, and Minna, J D, American fournal of Medicine, 1972, 52, 679.

18 Oken, D E, Nephron, 1971, 8, 505.

19 Earley, L E, New England fournal of Medicine, 1970, 282, 1370.
20 Lancet, 1973, 2, 134.

21 Vassalli, P, and Richet, G, in Proceedings of the First International Congress. of Nephrology, ed G Richet, p 236. Basel, Karger, 1961.

22 Wardle, E N, and Wright, N A, Archives of Pathology, 1973, 95, 271.

${ }^{23}$ Bonnar, J, McNicol, G P, and Douglas, A S, British Medical fournal, 1969, 3, 387.

${ }^{24}$ Charytan, C, and Purtilo, D, New England fournal of Medicine, 1969, 280, 1102.

25 Norman, P S, fournal of Experimental Medicine, 1958, 108, 53.

${ }^{26}$ Astrup, T, Thrombosis et Diathesis Haemorrhagica, suppl 54, p 83.

27 Lancet, 1974, 2, 1430.

${ }^{28}$ Naeye, R L, New England fournal of Medicine, 1961, 265, 867.

29 Howie, P W, et al, Lancet, 1970, 2, 1329.

${ }^{30}$ Bergstein, J M, and Michael, A F, Fournal of Laboratory and Clinical Medicine, 1972, 79, 701.

\title{
Secretion of immunoreactive calcitonin by human breast carcinomas
}

\author{
R C COOMBES, G C EASTY，S I DETRE，C J HILLYARD，U STEVENS，S I GIRGIS, \\ L S GALANTE, L HEYWOOD, I MACINTYRE, A M NEVILLE
}

non-endocrine tumours, including a squamous-cell carcinoma of the bronchus and seven out of eight consecutive breast carcinomas. ${ }^{5}$ The latter association is of particular interest since patients with breast carcinoma may have high levels of circulating immunoreactive calcitonin. ${ }^{6}$

\section{Summary}

Twenty-three out of 28 patients with metastatic breast carcinoma and one out of 13 patients with localised disease had raised levels of plasma immunoreactive calcitonin. Monolayer cultures of breast carcinomas maintained for up to 10 weeks released immunoreactive calcitonin, and a primary breast carcinoma passaged in "nude" mice for over a year contained material immunologically and chromatographically resembling the monomeric form of human calcitonin.

These studies indicate that breast carcinomas can produce calcitonin and that plasma calcitonin measurements may be useful in staging patients with breast carcinomas.

\section{Introduction}

Extrathyroidal secretion of calcitonin has been suggested by finding increased concentrations of immunologically or biologically active hormone in a variety of endocrine tumours ${ }^{1-3}$ and an oat-cell carcinoma of the bronchus. ${ }^{4}$ Using extraction procedures we have detected immunoreactive calcitonin in

\footnotetext{
Unit of Human Cancer Biology, Ludwig Institute for Cancer Research and Royal Marsden Hospital, London

R C COOMBES, MRCP, MRC clinical research fellow

G C EASTY, PHD, senior grade scientist

$S$ I DETRE, BSC, junior technical officer

U STEVENS, technical officer

A M NEVILLE, MD, MRCPATH, professor of experimental pathology

Endocrine Unit, Royal Postgraduate Medical School, Hammersmith

Hospital, London W12 0HS

C J HILLYARD, BSC, scientific officer

$S$ I GIRGIS, $\mathrm{MB}, \mathrm{BCH}$, honorary research assistant

L S GALANTE, PHD, honorary assistant lecturer

L HEYWOOD, junior technician

I MACINTYRE, PHD, FRCPATH, professor and director of unit
}

This observation, and the urgent need for a satisfactory marker for breast cancer, ${ }^{7}$ prompted us to carry out studies in vitro and in vivo to establish whether calcitonin is actually produced by breast carcinomas, and not simply stored or adsorbed by them. We also wanted to determine whether calcitonin estimations could be useful in the staging of this disease.

\section{Patients and methods}

Fasting venous blood samples were obtained from 72 patients with breast disease. The samples were placed on ice and immediately centrifuged for 10-20 minutes, and the plasma was separated and stored at $-20^{\circ} \mathrm{C}$ until immunoassay, which was within two weeks of collection.

Thirty-five consecutive patients were awaiting surgery at the Royal Marsden Hospital, 17 consecutive patients were attending the radiotherapy department of Hammersmith Hospital for postoperative radiotherapy, and the remaining 20 patients were inpatients on the radiotherapy wards. All except two were normocalcaemic and were not suffering from renal failure, liver failure, or any other form of malignant or endocrine disease known to be associated with hypercalcitoninaemia.

Each patient was placed in one of four groups depending on the histology of the tumour removed and the presence or absence of distant metastases as disclosed by full biochemical profile, bone and liver scans, bone marrow aspiration, and skeletal survey. Fourteen patients had benign disease, 13 had cancer localized to breast and lymph nodes, 17 were recovering from mastectomy, and 28 had metastatic disease. Those patients from whom samples were obtained three to four weeks after mastectomy had no evidence of metastatic disease as determined by these criteria. The control group of 69 patients has been described. ${ }^{6}$

\section{PREPARATION OF MONOLAYER CULTURES OF BREAST CARCINOMAS}

Twenty-one consecutive breast tumours were studied: 15 were histologically proved carcinomas and six were fibroadenomas (see table). Tumour tissue, removed at operation, was immediately placed in medium 199 (Bio-Cult Labs) containing 0.05\% penicillin and 